\title{
THE SMALL CLAIMS AND ACCESS TO JUSTICE* DISPUTE RESOLUTION: TRENDS AND ISSUES
}

\author{
PAUL NEJELSKI**
}

Many alternatives to the official courts are appearing in the United States to settle small claims disputes. In presenting an overview of the American experience, the author poses many fundamental questions on the policies which inform the litigation process. From this discussion 'an outline of the 'ebb and flow' of reform of judicial structures arises, adding perspective to the proposals to change the small claims court.

\section{INTRODUCTION}

This paper attempts to describe what has been happening in the United States in a broad range of dispute resolution both in and outside of court. These are the observations of a single individual, not - unfortunately the result of any large scale research effort. One other warning: any overview such as this tends to give extra emphasis to innovative ideas and practices, rather than the everyday or traditional.

The focus will be civil disputes rather than criminal. The typical dispute will be between two private parties - perhaps an automobile accident or a merchant/customer dispute. The norm will be a trial in court, although various alternatives in and around the courts shall be explored.

Anyone appraising or developing dispute resolution systems in either of our countries will probably have to consider these five questions at least: 1) Should dispute resolution be in court? And, if so, what part of the court? 2) How much simplification or efficiency is desired? 3) How do cases come into dispute resolution systems? 4) Are lawyers necessary? 5) Do we want adjudication or something else such as mediation?

\section{SHOULD DISPUTE RESOLUTION BE IN COURT?}

The United States has long had a continuum of dispute resolution in court, on the fringes of court and in alternatives out of court.' ${ }^{\prime}$ For example, arbitration outside of the courts - particularly of commercial disputes - has been well known since the eighteenth century. During the last two decades there has been a trend to require arbitration as a predicate to receiving a trial in court.

An even more popular alternative is the creation of administrative agencies to handle discrete areas of the law, such as workers' compensation or traffic. The creation of separate agencies is not necessarily justified in the name of efficiency, but rather in some instances to get away from real or perceived judicial bias. For example, the National Labor Relations Board was created in the 1930's because there was enough sentiment that most judges at that time were pro-management and would interpret any remedial legislation against unions and the work-

* The following two articles were originally presented at a national conference entitled "The Small Claims and Access to Justice" which was sponsored by the Canadian Institute for the Administration of Justice and held in Vancouver, B.C., from January 27.30, 1982.

** Circuit Executive of the Third Circuit in Philadelphia. These are personal remarks and do not reflect the policy of any present or past employer.

1. For a further descussion of this topic with a bibliography and a list of pertinent organizations, see P. Nejelski and L. Ray, "Alternatives to Court and Trial" in The Improvement of the Administration of Justice Fannie J. Klein ed., (1981) 263. 
ing man. The political decision was made to create a body which would be more responsive to a politically powerful group in society.

The relatively recent creation of housing courts in the United States suggests an interesting attempt to combine the features of a court with those of an administrative agency. For instance, some housing courts have their own investigators to check for building code violations or to enforce the judgments of the court. They may have screening officers such as clerk magistrates who resolve many of the cases at intake.

The housing court may also demonstrate the desire to go outside the normal recruitment procedures. In a least one court, the citizens' groups representing both landlord and tenant interests which initially lobbied for the legislation creating the court, also interviewed candidates for the newly created judgeship and made successful recommendations to the appointing authorities.

Although the ombudsman movement has been stronger in Canada than in the United States, its growth, however small in the States, is an important advocate for the "little guy". The ombudsman model has the advantage of combining to some extent the roles of judge and lawyer, and it may be an excellent alternative to a court proceeding.

A fundamental question is whether dispute resolution should be handled retail on an individual basis such as in the small claims court, or wholesale, e.g. by a class action in court. The decision of individual cases may be retrogressive to the extent that a fraudulent manufacturer may only have to pay $10 \%$ of the claimants who have been able to bring their case to court, whereas a class action or an executive action, by the Federal Trade Commission, for example, might be a better social response. Similarly, there are important questions of institutional capacity about whether the appropriate body for setting the substantive law is the legislature by passing a statute or code, or whether it is a court operating in the creative common law tradition.

Much of the answer to both these questions in our country depends to some extent on whose ox is being gored. There is considerable jockeying between liberals and conservatives (often depending on who is in control of which branch of government) about the proper role of the legislature vs. the court and how much activism should be allowed, particularly in the judicial branch.

Competition in the dispute resolution "market" may be more of a phenomenon in the United States than in Canada. Perhaps the archetypal current example is the Rent-A-Judge statute in California. ${ }^{2}$ Although enacted approximately 100 years ago, the statute has only been used with relative frequency in the last few years. It allows the parties to select a neutral party (perhaps a retired judge, another lawyer, or even a layman) to adjudicate their case. The case is referred from the court to this third party who hears both sides under whatever conditions they may wish to set - just on the papers, oral presentation for only an hour for each side, etc.. A decision is rendered by the private adjudicator which the court enters as its judgment. The decision is enforceable as the judgment of the court, allowing an appeal to the normal courts.

2. Cal. Civ. Proc. Code 88 638-645 (West 1976 and Cum. Supp. 1981) (first enacted in 1872). See also B. Christensen, "Private Justice: California's General Reference Procedure" (1982) A.B.F. Res. J. 79. 
A number of judges in California have taken early retirement or simply quit the bench in order to become part of this private judiciary. For them and for their clients, it has many advantages. For instance, the private judges work when, where and with whatever types of cases they wish. "Referencing out" puts cases into the appellate system years ahead of the normal procedures, which may be delayed as much as five years in areas such as Los Angeles.

The California reference out system has been criticized as creating a first-class treatment for those with enough money. But the total cost of the expedited procedure may be cheaper for the clients because of the significantly smaller amount of time spent by lawyers.

Whatever the merits of the California "Rent-A-Judge" system, it is clear that there is a growing potential for non-judicial adjudiciation dispute resolution under the rule of law by people who are not full-time judges. These individuals may be special masters. They may be referees. They may be lawyers, retired judges or law professors who are hired to give a quick estimate of a case or to supervise some or even all of the litigation process.

In many ways, this competition is vital to the formal justice system. It helps combat formalism and the type of mentality which is natural in any monopoly - especially one created by the state. The United States has a tradition in education of private and church schools which provide some measure of competition for the public schools. Similarly, there are a variety of alternatives to adjudication. Neither public nor private sponsorship is necessarily ideal; but, given the imperfections of human institutions, some competition is useful.

The existence of alternatives, however, does not mean that the courts and the formal justice system have no role to play or can simply ignore these developments. There is a long history of private vs. public dispute resolution in the United States, and not all of the private side is laudable. One example is the church-centred society in 17th Century Puritan New England where decisions were made by the elders of the church and dissenters driven from the community. Later instances of private dispute resolution include the lynch mob or the Ku Klux Klan. Not all private dispute resolution deserves emulation. The formal justice system has a duty to monitor and to play a role in the various types of informal dispute resolution to insure their basic fairness and proper functioning.

Running throughout the debate about what should be in court and what should be outside is hopefully a growing awareness that the criteria is not just what is best for the court and the judges, but also what is the impact on relevant others - lawyers and the legal profession, the client, the public and the taxpayer? Much of court reform in the past has been from the top down, focusing on issues such as court unification or merit selection of judges which may have little impact on the actual conduct of litigation. Questions should also be asked about the impact on the client of a change in procedure or dispute resolution.

Assuming a case is in court, what part of the court should it be in? There is a growing hierarchy in both the state and federal courts. A few cases, perhaps 150 to 200, will be resolved in the federal Supreme Court on the merits. The federal intermediate Courts of Appeals are growing under substantial increase in cases decided per judge, as well as in total 
numbers. Whereas judges on the Third Circuit might have averaged about 80 cases a year in 1968, they now average 250 appeals per year. Several of these courts have responded by creating a "settlement program" staffed with para-judges.

The district or trial courts in the federal system have adopted a variety of procedures to cope with the enormous growth in cases. There are separate judges in bankruptcy. The magistrates have been given much broader powers than they had in the past. A typical ratio is one full-time magistrate for every three federal judges. Magistrates originally heard only relatively minor criminal matters or handled arrest and search warrants. Now they handle almost any phase of the litigation, including, with the consent of the parties, the trial of any civil matter.

In addition to these fairly visible adjudicators, there are the clerks and their staffs, the personal law clerk to the judge ("elbow" clerks) or the central staff attorneys (who in the 9th Circuit Court of Appeals number 30 attorneys for 23 judges). These assistants either deal directly in resolving these cases or assist judges by performing legal research, summarizing evidence, etc..

Consequently, even if the case is in court and being decided by the judge, the question arises: how much assistance is being given to that judge by others in the system? Certain types of cases may routinely be reviewed in the clerk's office, such as prisoner petitions, before they are even seen by a judge. Some types of cases, such as review of social security denials, may be routinely read and analysed by a magistrate, by the judge's "elbow" clerk or soon by the magistrate's "elbow" clerk - with the judge simply reviewing a memo and final order. At both the trial and appellate levels, questions are raised about the extent that judges are really deciding cases which are in court.

A variation on this theme of who will decide or resolve the dispute in court is the suggestion by Harvard Professor Frank Sander that the courthouse of the future will have many "doors", or forms of dispute resolution. For example, there have been several experiments in the federal system with court-annexed arbitration for commercial cases or mediation of prisoner complaints.

Another issue is whether the court should be in its own building. I remember much to my surprise when I clerked on the Appellate Division of the New Jersey Superior Court that the Newark courtroom was in a modern office building named for and owned by an insurance company! What would be the public perception of a small claims court located in the basement of a large chain store such as Sears Roebuck?

Even in a country such as ours which has gone to considerable lengths to separate the judicial from the legislative and executive branch, some like the symbolism of having the judiciary physically located in the same building as the legislative branch. The Supreme Court of the United States for its first decades met in the basement of the Senate wing of the Capitol Building. When a separate building was created across the street, some, (e.g. Justice Oliver Wendel Holmes, Jr.) protested the move on the grounds that the Supreme Court should be part of the legislative building because the judges were giving present expression to the past actions of the legislature. Similarly, it is not unusual in state governments to find the supreme court in the same building with the legislature and the governor. 


\section{HOW MUCH SIMPLIFICATION AND EFFICIENCY IS DESIRED?}

Controversies over simplification vs. formalism have run throughout the history of the dispute-resolving process in the United States. In colonial Massachusetts, there was an attempt to get away from formalities and lawyers. One by-product was oral rather than written pleadings - a reform which caused more problems than it solved.

One proposal to make appeals quicker and hopefully less expensive is to have very short briefs and an emphasis on oral argument - in the mode of the English system. An experiment has been run in Sacramento, California, which demonstrates that appeals, at least in certain types of cases numbering perhaps half of the appeals on the docket, can be heard within 71 days of entering the program. However, some may argue that a court needs more time for deliberation and that 6 days, which the Sacramento program is averaging from oral argument to filing the decision and judgment, is too fast.

In a similar vein, an economical litigation program can process cases from the filing of the complaint with limited discovery to trial within seven or eight months. Is this too fast? Not fast enough? That may depend on the type of case, but a number of experiments have demonstrated that litigation can be resolved quickly when the judges, their support staff, lawyers and all concerned choose to honor a relatively speedy disposition. At the federal level, the Criminal Speedy Trial Act ${ }^{3}$ has shown that the vast majority of cases ( $90 \%$ plus) can be resolved in the time periods specified by the statute.

But there may be costs for each of these simplifications or efficiency measures. For example, criminal defense counsel call the federal Speedy Trial Act, the "Speedy Conviction Act". The prosecutor may take weeks or months to develop a case, interview witnesses and proceed to the grand jury when they are ready. In contrast, the accused is suddenly put into the difficult position of having to defend on relatively short notice and under tight time limitations.

The appearance as well as the actuality of justice is important. We are all offended by the same day indictment, trial and execution in Iran, but how fast should a normal civil case take? Is there some value in letting disputes "cool off"? Whether or not judicial intervention in pretrial stages in civil litigation is justified is still an open question. Particularly in divorce cases, it is said that the case will only make progress after the parties begin to dislike their lawyers and the courts as much as they dislike one another!

An interesting experiment concerns the court's giving the tentative ruling or even circulating its draft opinion before the argument. This is a continuum. Most courts in hearing an oral argument may suggest to counsel at the beginning of the presentation the points on which argument would be particularly helpful. If that is acceptable, why not convey the information in a short letter to counsel the week before the argument in order to facilitate preparation? If that is permissible, why not give counsel a tentative ruling and perhaps some reasons or authorities thought to be controlling? And if that is acceptable, why not give them the 
draft opinion where it exists - as it does in many state intermediate courts of appeals? Where this has been tried, counsel and the court have generally been enthusiastic about the circulation of opinions prior to argument. However, others may be horrified that circulation of the tentative opinion is an "Alice in Wonderland" procedure of "decision first, argument later".

How much pomp and circumstances is required? I remember hearing about a commission which attempted to draw up standards for what a juvenile court in the United States should look like and how it should act. Should the judge wear a robe and sit on a bench, appear in a business suit, or even shirt-sleeves at a round table with the juvenile, his family and the complaining witness, in a more informal atmosphere? After much deliberation, the only criteria that everyone could agree upon was that there should be an American flag in the room!

Similarly, there is a continuum in the other courts of formality and informality. Some judges hear motions in their chambers without a court reporter. Others only hear motions in open court with a court reporter taking down every word. The use of the telephone for argument of motions and conducting other business has encountered some of these same problems. Some judges are horrified that their colleagues may be taking a plea of guilty in a minor case or hearing arguments for summary judgment by telephone rather than in the courtroom with all the formalities.

Where the total effect is to save money and time for the court, for the lawyer and hopefully for the client, we may need to ask ourselves - "Why not adopt more simple and informal procedures?" However, there may be limits. If a whole hearing were to be conducted by telephone, will there be more perjury or witnesses taking the proceedings too lightly? On the positive side, there have been studies of administrative hearings completely by telephone, and the evaluators found that there has been little or no difference in terms of the result, or the impressions of the parties, their counsel and the judge. Indeed, in some cases there has been a more positive reponse to telephone hearings, especially by the complaining witness.

\section{HOW DO CASES COME INTO DISPUTE RESOLUTION SYSTEMS?}

Cost and delay currently screen cases. Many cases simply are not brought because it would take too long or the cost would be too great - or both. A study being conducted by the University of Wisconsin indicates that only a small fraction of relatively serious disputes (i.e., those over a thousand dollars) is actually brought to a lawyer and an even smaller number is brought into court. Many of these cases may be frivolous and perhaps should not be in the courts. But at least the individuals interviewed in the study thought that they had been wronged, either in tort, contract or through some kind of discrimination. And they were usually barred from pursuing a remedy through cost and delay in the system. Is it our objective that anyone can litigate any question at no cost to themselves and receive a quick response? What would happen if there were no cost and delay in litigation?

The question of fee-shifting or the loser having to pay at least to some extent for the attorney's fees and costs of the winner is probably one of the greatest differences between our countries. However, the trend in 
the United States seems to be toward the English rule. Arizona ${ }^{4}$ has recently passed a statute allowing a fee shifting in contract cases. Idaho ${ }^{5}$ has given trial and appellate judges power in all cases to assess fees and costs. Alaska ${ }^{6}$ has had fee shifting since its admission as a state in 1959. Whether this will lead to less litigation as suggested by its champions, or merely present an obstacle to settlement and speedy resolution of the cases, remains to be seen. There is a growing recognition of the differential effect of fee-shifting; i.e., the effect will vary for different types of cases or litigants. Consequently, generalizations may be difficult about who gets what, when and where under fee shifting. One thing is certain: fee shifting will have a chilling effect on bringing cases to establish new doctrines and could cause additional problems for the already hardpressed public interest bar.

Economic incentives or disincentives are crucial to the dispute resolution process but have received little attention. Most parties who owe money would rather pay it later since there is no, or little, prejudgment interest, and the defendant, at least currently, can invest at very high interest rates and make a great deal of money. Similarly, because of high inflation, parties who owe money would rather pay in two or three years or even five years when the amount owed will be worth much less. Consequently, we need to take a hard look at the role that delay and costs play in litigation.

In addition, there is the question of repeat players vs. the single shot or one time litigant. The legal system favors those who become familiar with the procedures through repeated appearances.

Who should be allowed to be the gatekeeper and what criteria should be employed has been an increasingly political question in the United States. The hostility of some federal leaders to allowing poor people to have representation through the Legal Services Corporation and have their day in court is simply one example of the important consequences of these decisions.

\section{ARE LAWYERS NECESSARY?}

Lawyers add to the delay and the expense of dispute resolution. A minimum fee for lawyers would be (e.g., in the District of Columbia) $\$ 50$ an hour and prices go up much higher so that some corporate clients are paying $\$ 200$ or $\$ 300$ an hour. Given those kinds of costs, it is difficult to develop inexpensive systems which involve lawyers.

Indeed, one of the great advantages of the community or neighbour hood justice centre movement is that lawyers generally are not present - either because mediation makes an adversary model inappropriate or because the cases are so small that a lawyer's fee would not be warranted. An important question is whether lawyers will continue to allow these types of small cases to be diverted outside the legal system.

The Jacksonian revolution in the early nineteenth century sought to open up the admission of practice. It encouraged almost anyone to be their own lawyer or to make the requirements to being a lawyer relatively

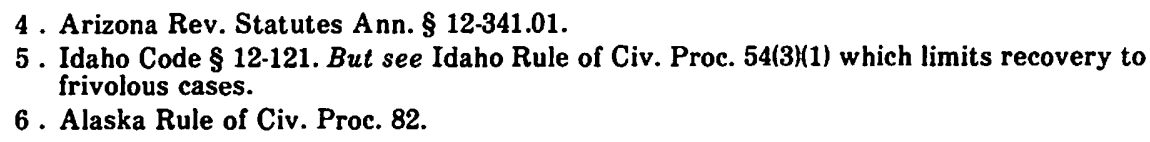

5. Idaho Code § 12-121. But see Idaho Rule of Civ. Proc. 54(3)(1) which limits recovery to frivolous cases.

6. Alaska Rule of Civ. Proc. 82. 
minimal. Of course, extreme democratization of the profession has deleterious effects as well as positive. People in such a system may hold themselves out or indeed be certified as lawyers who actually have little training or competence. Lawyers have been the subject of invective over the years, from Carl Sandberg to radical writers at the time of the revolution and before. Indeed, several colonies prohibited lawyers. Much can be and has been said which is unpleasant about lawyers in the United States.

(1) There are too many lawyers. There are over 500,000 lawyers now, and their ranks are growing dramatically. No country has more lawyers per capita. A serious question is why such a large group has produced so little of social utility. Any attempt to limit the large number of lawyers in the United States would probably be met with a response from the Federal Trade Commission or the Department of Justice even under the truncated anti-trust enforcement of the current Administration.

(2) Lawyers have stopped reforms. Although there have been notable examples of leaders of the bar such as former ABA presidents Orison Marden, Leonard Janofsky and others who have been steadfast champions for legal aid for the poor and other reforms, the rank and file either have been indifferent or fought reforms such as nofault insurance.

(3) The profession has been slow to police unethical conduct. This area is changing slowly for the better with the growth of at least perfunctory teaching in law school of legal ethics and the creation of ethics panels at the state bar level. However, there is shockingly little guidance about how attorneys should charge. Lawyers give themselves bonuses, cut themselves in on the profits gained through their efforts, charge by transaction regardless of how many hours they have spent, etc.. As a result, many corporations and insurance companies are doing more legal business themselves rather than engage private counsel.

(4) Self-interest is paramount. Lawyers have isolated themselves, often from the bench, and certainly from society. Their concern is largely with how changes will impact on themselves and their ability to make money. While this is certainly understandable, it is not necessarily laudable. Where a court may impose a non-continuance policy in an attempt to speed up processing of cases, the bar especially acting through the legislature - may retaliate by cuts in the judicial budget or by passing legislation which overrules a rule created by the judiciary.

(5) Lawyers lack social conscience. There is a distressing but growing movement among bar associations to cut out any activities which give service or assist the public in any way. These reactionaries would limit the payment of bar association dues only to the bare essentials required by state supreme court edict or statutes. For example, the District of Columbia bar has cut out the use of dues money for continuing legal education, lawyer referral or assistance programs of any kind. This refusal to provide anything in return for a state created monopoly is reprehensible.

Regardless of the ethics and practices of the lawyers, market forces are said to be at play which will improve service and reduce the costs. Adver- 
tising by lawyers is now permitted, although infrequently used to date. Fee schedules have been abolished by the U.S. Supreme Court with the result that set fees for specific transactions or types of work are no longer to be suggested, much less enforced. However, the average consumer may not know what fee is appropriate, and it is hard to shop around for lawyers. Promising signs include (1) the creation of clinics for routine problems and (2) the growing awareness of large corporations and insurance companies, who are repeat players in dispute resolution arenas, that they have a serious interest in reducing costs.

Despite the unfortunate abuse by American lawyers of their monopoly status, it is still thought to be useful to have a lawyer if you are in trouble. But small claims courts may present a different picture. Small claims courts were set up in the United States in an attempt to minimize the role of lawyers; and, in some jurisdictions, they are barred from appearing. A central rationale of small claims courts was that average citizens could present their claims in a fast and inexpensive fashion. If one side appears with a lawyer, there may be a feeling that the other side should be represented. Or the judge should exercise special caution to make sure that the unrepresented party or parties are not disadvantaged.

\section{DO WE WANT ADJUDICATION OR SOMETHING ELSE SUCH AS MEDIATION?}

Populists have long attacked lawyers. Jimmy Carter's 1977 speech before the Los Angeles Bar Association correctly stated that we are "over lawyered but under represented" and that 90 per cent of the lawyers spent their time representing the top 10 per cent of the socioeconomic strata. But a schizophrenia continues about whether or not the social utility of lawyers and the rule of law exceeds their cost in society. Phrased another way - do we need the rule of law or is some other form of dispute resolution sufficient? Do people want justice or mercy? Law or equity?

Mediation is popular at a variety of levels, such as neighborhood justice centres, or in divorce cases in reaching a preliminary agreement about the custody of children or separation of property. Settlement negotiations conducted by a judge or others in court are receiving greater attention.

In mediation or even in arbitration, the parties can agree to their own procedures. But if there is inequality between the disputants - such as prisoners in an institution or the one-time customer vs. the company which handles hundreds or thousands of these cases every year - is mediation really effective? On the positive side there is some evidence that, at least in terms of warranties, some stores and merchants are willing to go beyond what the law allows simply to gain good will and resolve the problem quickly.

Roscoe Pound ${ }^{7}$ once contrasted the rule of law with discretion and justice - and found the rule of law superior. As indeed, I think, would most members of the legal community. However, as Pound admitted, and there is little denying today, there are strong forces for discretionary

7. R. Pound, "Justice According to Law" (1913) CoL. L. Rev. 696 and (1914) 14 Col. L. Rev. 1, 103. Reprinted, in Essays in Jurisprudence from the Columbia Law Review (1966) 217. 
justice in our contemporary society, such as neighbourhood mediation centers.

Indeed, judges, especially in our lower courts, normally perform several functions in addition to adjudication. They attempt to mediate and bring together parties even though the law, strictly interpreted, may favour one side or the other. Judges need training in a variety of roles and not just adjudication - as well as how and when to switch from one role to another!

Since 90 per cent of the cases, criminal, civil, juvenile, or family, settle before adjudication, it is important to recognize that the courts and the trial process provide a process for the facilitation of settlement. A firm trial date is a "Doomsday machine" which forces the parties and their lawyers to prepare the case simultaneously and hopefully resolve it. The parties must go through a certain amount of cost, delay and aggravation before they are willing to settle a case. But how well do our courts fulfill this function? Is settlement early or late in the process? With or without excessive expense?

Small claims courts may be an exception to the general reliance on mediation and settlements, at least to the extent that the number of trials exceeds 10 per cent. Given the often unequal bargaining power between the parties in small claims court and the lack of counsel, a high percentage of trials is to be favoured. The court in these situations has a special responsibility to protect unrepresented or disadvantaged parties.

Another symptomatic problem about the extent to which we want adjudication based on the rule of law is the degree to which opinions of the court are published, especially at the appellate level. Do we want to publish all opinions and make them available to the public and to lawyers - or only a handful? (This is a difficult policy question, since informal mechanisms spring up for publicaton and dissemination of "unpublished" decisions.) To what extent do we want precedent and the rule of law to govern? Do we want each judge or panel of judges to do the best they can with the facts of each case?

\section{CONCLUSION}

This discussion has raised a number of questions and attempted to show that the answers are not easy. The "solutions" may be neither clearly yes or clearly no. Even the question of whether we want lawyers in dispute resolution is difficult. Regardless of whatever criticisms I might have of lawyers and the profession in the abstract, I should not only want a lawyer but the best one available should I be involved in a commercial dispute or certainly in a criminal case.

The history of the administration of justice in the United States over the last three hundred and fifty years has never reflected a permanent solution but rather partial accommodations, given changing sensitivities, philosophies, and resources. There has been a cyclical creation of alternatives to trial and to courts - which in turn become courts - which after a time become broken off into administrative agencies or other alternatives. Perhaps this is a healthy development. It helps combat the formalism of a rigid judicial bureaucracy. Jefferson called for a revolution every twenty years; and our court reformers - although not necessarily in cycles of exactly two decades - seem to be creating alternatives (or courts) at relatively frequent intervals. 
For better or worse, these decisions about access to dispute resolution systems are political. The fights over whether diversity cases should be in federal court are an example. (These are contract and tort cases which ordinarily would be in state courts, but because the parties are from different states or countries, they can be filed or removed to federal court.) Similarly, controversies about whether civil liberties cases will be heard in the federal courts - generally considered to be first class treatment in the United States - or whether business interests will have their cases resolved there, are equally intense.

Whether small claims are resolved in courts or in non-judicial alternatives such as neighbourhood justice centers or through class actions or even by legislation have important ramifications. These issues, however, rarely raise to the level of public consciousness given other problems such as unemployment or national defense.

Often court reforms are cloaked in the guise of good government proposals. For example, court unification (the merging of courts of lower jurisdictions such as small claims into general jurisdiction courts) is a "good thing to do". But the basic political considerations are always close to the surface.

At the moment, the tides seem to be running away from full dress trials in court. On one level, there is interest in having disputes resolved outside the courts in alternative mechanisms. In court, there is an emphasis on simplified, more efficient mechanisms. The use of non-judicial personnel may increase - for example in the clerk's office, special masters or temporary judges. But there is a counter-pressure concerned about the appearance and the "feel" of justice. There is, in short, an ebb and flow on each of these questions.

The most important question has been saved for last: in whatever roles we may appear - as judges, lawyers, administrators, journalists, legislators, concerned citizens, voters, or taxpayers - have we created systems in which you or I or our families would like to have our disputes resolved? Or are these systems created for someone else - especially if they are poor or of another color?

The feeling that there should be no "second class" justice is strong and justified. However, does every case deserve a full dress trial in the court of general jurisdiction? It is ironic that several reforms at the higher levels of our courts, such as mini-trials or economic litigation, are borrowing techniques and philosophies from the lower courts and alternatives such as a "quick look", reduced adversarial presentation of facts, and mediation.

The challenge is to make the courts of limited jurisdiction and the other means of dispute resolution clearly acceptable so that there is no image or fear of second-class resolution of cases in the eyes of the parties or impartial observers. Unfortunately, our "lower courts" have been given the aura of a "latrine duty" in which a judge spends a few years in hope of moving up to something "better". How can everything be first-class? Should judges be rotated from top to bottom of a judicial system which is by nature extremely hierarchical? Are the taxpayers and legislators willing to create facilities that are as grand at the lowest levels, such as small claims and traffic court, as they are at the Courts of Appeals and Supreme Courts? 
Are society and the courts going to monitor what is happening in alternatives and in the lower courts? It is also not a question of creating some system in the abstract or by statute and then assuming that the plan has been implemented in the real world. There is a need to interview the people who use the courts, the lawyers who appear at them, the judges who are in the front line, and see what is really happening.

Too often we seek gimmicks and new formulations on the surface, rather than worry about the soul or the inner spirit of our problem. So much depends upon the individuals involved - their motivation, training, and goals. How something is done and by whom may be more important than which program is being implemented. A good idea or a combination of factors discussed above may be counter-productive, if the people running the system do not have a commitment to what they are doing.

Our justice systems are created by human beings like you and I. The choices are not preordained. There are few absolutely right or wrong ways. Like most policy choices, they are a difficult combination of practical expediency with considerations of values and morality. Often they call for a complex type of linear programming - confronting large problems with limited resources. It is important to discover how we might renew ourselves and our institutions. 